\title{
The Determining Factors of Local Own- Source Revenue of Tourism Sector in DIY
}

\author{
Agnes Ratih Ari Indriyani \\ Faculty of Economics and Business \\ Janabadra University \\ Yogyakarta, Indonesia \\ agnes@janabadra.ac.id
}

\author{
Burhanudin \\ Faculty of Economics and Business \\ Janabadra University \\ Yogyakarta, Indonesia \\ burhanudin@janabadra.ac.id
}

\author{
Andreas Ronald \\ Faculty of Economics and Business \\ Janabadra University \\ Yogyakarta, Indonesia \\ andreas@janabadra.ac.id
}

\begin{abstract}
Tourism is perceived as an economic engine that generates foreign exchange for economic development in a country, including in Indonesia. However, in principle, tourism has a broader fundamental spectrum of development for a country. This study aimed to determine to what extent the effect of population, Gross Regional Income per Capita, and number of restaurants affects the number of tourist visits and then how the impact of these various variables on regional economic performance, namely the Local Own-Source Revenue of Tourism Sector. This study used 25 secondary data from the Central Bureau of Statistics, Yogyakarta Tourism Office, namely DIY Tourism Statistics, various publications during the 2015-2019 period. The technique of data analysis used path analysis. The results of this study showed that the Gross Domestic Product per capita, the number of restaurants and tourist visits had a positive and significant effect on Local Own-Source Revenue of Tourism Sector and the number of tourist visits mediated the effect of population to Local Own-Source Revenue (LOSR) of Tourism Sector.
\end{abstract}

Keywords: local own-source revenue; tourism sector; path analysis

\section{INTRODUCTION}

The Law of Decentralization and Regional Autonomy provides opportunities for regions to develop their natural resources efficiently and optimally. Each local government seeks to improve the regional economy by obtaining Local Own-Source Revenue (LOSR). With this, the local government must innovate in order to develop the potential for the income of LOSR it has. The creative economy is one of the regional strategies to increase regional income which has an impact on increasing LOSR.

As the largest industry in the world, tourism has enormous potential to influence both positively and negatively in environmental aspects, as well as on world social and economic conditions [1]. Over the past decade tourism in developing worlds has expanded at a rapid rate and will continue to flourish in the foreseeable future (2). The role of the national tourism sector is increasingly important in line with the development and contribution provided by the tourism sector through foreign exchange earnings, regional income, regional development, as well as in absorption of investment and labor as well as business development scattered in various parts of the region [3]. In Indonesia, the contribution of the tourism sector to the national Gross Domestic Product (GDP) in 2019 has reached 4,8\% or Rp. 480 trillion. Meanwhile, foreign exchange from the tourism sector in 2018 reached IDR 280 trillion and contributed 12,7 million (10\%) people to employment opportunities [4]. Through the mechanism of attraction and push towards other economic sectors related to the tourism sector, such as hotels and restaurants, transportation, the handicraft industry and others. Through the multiplier effect, tourism can and is able to accelerate economic growth and job creation. That is why, accelerating economic growth and creating wider employment opportunities can be done by promoting tourism development [5]. It is in line with accordance with the research findings of [6] that the increase in revenue from the tourism sector, will remind the social, economic and social infrastructure of the tourism sector.

Tourism is able to have a positive impact in an effort to contribute to foreign exchange earnings, increase employment opportunities, increase revenues from the central government, especially regions and communities as well as the introduction of culture [7]. A tourism, if it is developed properly, it will have a positive impact on tourists and communities that provide these tours through economic benefits that are brought to the tourist area. With increased revenue, the government can develop infrastructure and provide facilities so that tourists and local residents benefit from each other. Therefore, it is said that tourism can be very important in the local context despite considerable leaks [8]. The success of developing the national tourism sector cannot be separated from local tourism in the regions. Tourism revenues contribute positively to economic growth in developing countries. The results of a research show that developing countries' governments should focus on economic policies to promote tourism as a potential source of economic growth [9] One of the provinces in Indonesia that has attractive tourist destinations is the Special Region of Yogyakarta (DIY) province. DIY Province has natural tourism with various beauties such as beach tourism destinations, as well as mountains and several cultural heritages such as temple buildings and historical sites. In terms of location / location DIY Province is located in a strategic part in the middle between West Java and East Java provinces and in the southern part of Central Java province which allows tourists to 
visit. Judging from the various topographic conditions in DIY province, ranging from the form of plains, mountain slopes and coastal areas.

In 2015-2019 the number of LOSR in the tourism sector in DIY has always increased. The tourism industry in DIY, starting from 2012, is growing rapidly, it can be seen that the LOSR in the DIY tourism sector has an increasing trend from 2015 to 2019 [10]. The tourism sector in DIY which continues to grow has an impact on local revenue. The greater the LOSR produced by a region can improve the regional economic structure and can increase independence and competitiveness, thus it is expected to provide welfare for its people.

The problems in this research are:

1. What are the factors that influence the number of tourist visits to DIY.

2. How much influence do economic and tourism-related variables affect the number of tourist visits in DIY and how do they impact Local Own Source Revenue

\section{DATA AND METHOD}

\section{A. Data Source}

This research uses quantitative methods. The sample of this study used 25 secondary data from the Central Bureau of Statistics, during the 2015-2019 period. In addition, data was also obtained from the DIY Tourism Office, namely the DIY Tourism Statistics, various publications.

\section{B. Method}

Selection anda Definition of the Model Variable

The operational definition of the research variables is described as follows:

a) Total population (X1) is the number of people who are domiciled and settled for $<6$ months or more in DIY province in 2015-2019. Population data is measured in people.

b) GDRP Per capita (X2) is the share of regional income from a region and the population in a certain area in a certain year, which is shown by GDRP per capita based on the prevailing prices in 2015-2019. GDRP per capita data is measured in rupiah units.

c) Number of restaurants (X3) is the number of restaurants that have received guidance from districts / cities in the DIY province in 2015-2019. Data on the number of restaurants is measured in units.

d) The number of tourist visits (M) is the number of foreign and domestic tourists visiting districts / cities in DIY province in 2015-2019. Data on the number of tourist visits is measured in units of people.

e) LOSR in the tourism sector (Y) is a fee or other levy in the form of a levy from a person or agency running tourism business activities given to district / city governments in the DIY province in 2015-2019. LOSR tourism sector data is measured in Rupiah units.
1) Econometric Model

The data analysis technique used path analysis with regression analysis tools and single test with the help of SPSS 21 software and Process 3.4 software. The research criteria used in the simple regression test to accept or reject the proposed hypothesis are by comparing the probability value of the t test (p-value) with the significance of alpha $(\alpha)=0.05$. If the t-test probability value ( $\mathrm{p}$-value) is less than 0.05 , then Ho is rejected and $\mathrm{Ha}$ is accepted, which means that the independent variable individually has a significant effect on the dependent variable. While the sobel test criteria is to compare the coefficient of direct effect and coefficient of indirect effect of the independent variable on the dependent variable. If the direct effect coefficient is smaller than the indirect effect coefficient, Ho is rejected and $\mathrm{Ha}$ is accepted, which means that the effect of the independent variable on the dependent variable is mediated by the mediating variable [11].

The Path Analysis Equation is presented as follows:

$\log (Y)=\beta 1 \log (X 1)+\beta 2 \log (X 2)+\beta 3 \log (X 3)+\beta 4 \log$

$(\mathrm{X} 1 \mathrm{M})+\beta 5 \log (\mathrm{X} 2 \mathrm{M})+\beta 6 \log (\mathrm{X} 3 \mathrm{M})+\mathrm{e}$

Information :

$\beta 1, \beta 2, \beta 3, \beta 4, \beta 5, \beta 6=$ parameters

$\mathrm{Y}=\mathrm{LOSR}$ in the tourism sector

$\mathrm{X} 1=$ Total population

$\mathrm{X} 2=$ GRDP per capita

$\mathrm{X} 3=$ Number of restaurants

$\mathrm{X} 1 \mathrm{M}=$ Total population by number of tourist visits

$\mathrm{X} 2 \mathrm{M}=$ GRDP per capita through the number of tourist visits

$\mathrm{X} 3 \mathrm{M}=$ Number of restaurants through number of tourist visits

e $\quad=$ error term

\section{RESULT}

The results of the research using regression analysis and the Sobel test are presented in Figure 1 below.

$\log (y)=0,56 \log (x 1)+2,197 \log (x 2)+0,576 \log (x 3)$

$+(0,370 \times 0,671) \log (x 1 M)+(0,623 \times 1,787) \log (x 2 M)$

$+(0,268 \times 0,429) \log (x 3 M)$

$\log (y)=0,562 \log (x 1)+2,197 \log (x 2)+0,576 \log (x 3)$

$+1,814 \log (x 1 M)+0,349 \log (x 2 M)$

$+0,625 \log (x 3 M)$

Information:

$\mathrm{X} 1=$ population

$\mathrm{X} 2=$ GDRP per capita

$\mathrm{X} 3$ = number of restaurants

$\mathrm{M}=$ number of tourist visits

$\mathrm{Y}=$ LOSR tourism sector 


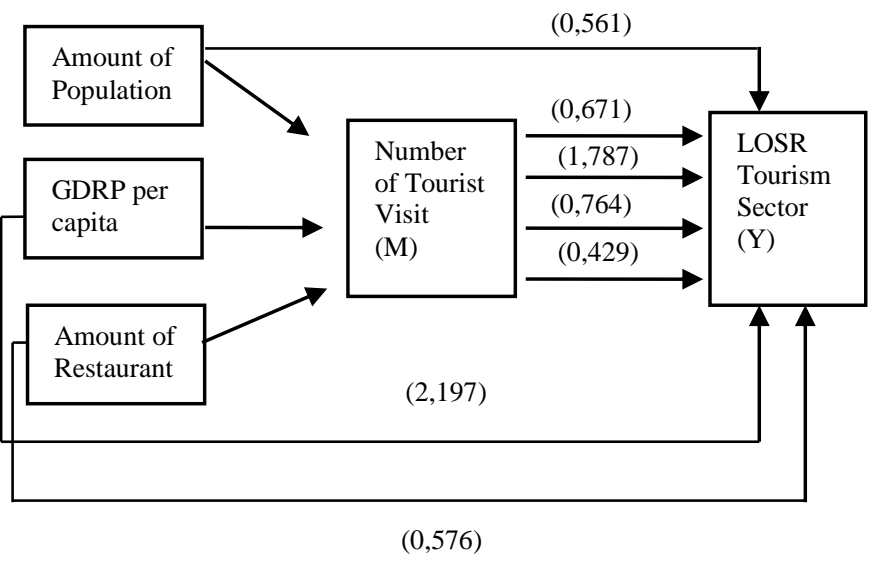

Source: Secondary data processed, 2019

Fig. 1 Result of Data Processing

Table $1 \quad$ Results of Data Processing

\begin{tabular}{|c|l|c|c|c|c|}
\hline $\begin{array}{c}\text { Hypo- } \\
\text { thesis }\end{array}$ & Effect & $\begin{array}{c}\text { Effect } \\
\text { Direct- } \\
\text { ion }\end{array}$ & Coefficient & $\begin{array}{c}\text { Probability } \\
\text { (p-value) }\end{array}$ & Conclusion \\
\hline $\mathrm{H} 1$ & $\mathrm{X} 1 \rightarrow \mathrm{M}$ & + & 0,370 & 0,167 & Rejected \\
\hline $\mathrm{H} 2$ & $\mathrm{X} 2 \rightarrow \mathrm{M}$ & + & 0,623 & 0,012 & Received \\
\hline $\mathrm{H} 3$ & $\mathrm{X} 3 \rightarrow \mathrm{M}$ & + & 0,268 & 0,002 & Received \\
\hline $\mathrm{H} 4$ & $\mathrm{X} 1 \rightarrow \mathrm{Y}$ & + & 0,561 & 0,358 & Rejected \\
\hline $\mathrm{H} 5$ & $\mathrm{X} 2 \rightarrow \mathrm{Y}$ & + & 2,197 & 0,000 & Received \\
\hline $\mathrm{H} 6$ & $\mathrm{X} 3 \rightarrow \mathrm{Y}$ & + & 0,576 & 0,004 & Received \\
\hline $\mathrm{H} 7$ & $\mathrm{M} \rightarrow \mathrm{Y}$ & + & 1,787 & 0,000 & Received \\
\hline $\mathrm{H} 8$ & $\mathrm{X} 1 \rightarrow \mathrm{M} \rightarrow \mathrm{Y}$ & + & 0,671 & - & Received \\
\hline $\mathrm{H} 9$ & $\mathrm{X} 2 \rightarrow \mathrm{M} \rightarrow \mathrm{Y}$ & + & 0,764 & - & Rejected \\
\hline $\mathrm{H} 10$ & $\mathrm{X} 3 \rightarrow \mathrm{M} \rightarrow \mathrm{Y}$ & + & 0,429 & - & Rejected \\
\hline
\end{tabular}

Source: Secondary data processed, 2019

\section{DISCUSSION}

The results of data processing listed in Figure 1 can be explained as follows

\section{A. The Effect of Total Population on the Number of Tourist Visits}

The results of this research indicate that the population has a positive and insignificant effect on the number of tourist visits to districts / cities in the province of DIY, because it has a positive regression coefficient $=0.370$, with a probability $=$ 0.167 which is greater than 0.05 . This means that for every $1 \%$ increase in population, the number of tourist visits will increase or increase by $37 \%$, but the increase in the number of tourist visits caused by the population is not significant in real terms.

The results of this research are in accordance with the statement of [12] that an increase in population does not in itself cause changes in tourism demand. But population changes have been followed by developments in employment opportunities. Thus, if there are more job opportunities, more people will receive or earn income per capita, so that it will increase people's purchasing power. This means that if the increase in population is not accompanied by an increase in job opportunities that can automatically increase the purchasing power of the community, the number of tourist visits tends to be constant or even decrease.

The results of this research are different from the theory expressed by Mc. [13] states that an increase in population in an economy assuming a constant per capita income shifts market demand to the right which applies to most tourism goods / services. It means that the increasing number of populations in a country with the assumption of constant per capita income will increase the demand for tourism activities. With the increase in population, it is hoped that there will also be an increase in the number of tourist arrivals from one country to the tourist destination country, Mc Eachern theory (2000) is similar to the statement from Lumaksono et al. (2012) which states that the population of an area is also one of the variables that affects the number of tourist visits [14]. The more the population increases, the more people will travel on tour.

\section{B. The effect of GDRP per capita on the number of tourist visits}

Based on the results of simple regression analysis, it shows that the GDRP per capita has a positive and significant effect on the number of tourist visits, for it has a positive regression coefficient $=0.623$, with a probability $=0.012$ which is smaller than 0.05 , so the second hypothesis which states "GRDP per capita has a positive effect on the number of tourist visits "accepted / proven. This means that every increase in GDRP per capita by $1 \%$, the number of tourist visits will increase or increase by $62 \%$.

The tourism sector can have an influence on GDRP Per capita through economic activities created in the tourism industry such as fulfilment the needs of tourists for hotels, transportation, restaurants and other services that can contribute to the Gross Regional Domestic Product (GRDP) of a region. GDRP Per capita is a reflection of the income of local communities (tourists) which has a positive influence on demand for tourism visits [15].

\section{The Effect of Number of Restaurants on the Number of Tourist Visits}

The results of the study using simple regression indicate that the number of restaurants has a positive and significant effect on the number of tourist visits because it has a positive regression coefficient of 0.268 with a probability value of 0.002 , which means that for each increase in the number of restaurants by $1 \%$, the number of tourist visits increases or increases by $26,8 \%$. These results can be concluded that the third hypothesis in the study which states that "the number of restaurants has a positive effect on the number of tourist visits" is accepted / proven. 
Tourist activities are closely related to culinary originating from these tourist destination areas. Culinary tourism activities can be an activity of choice for tourists to look for impressions that will be brought back to their place of origin. culinary tourism or culinary business is closely related to restaurants. In general, a full-service restaurant is a restaurant that provides a complete menu service where waiters bring orders and food to the customer's table. In theory, there are four types of elements present in restaurant products. These elements include food and beverages, atmosphere, cleanliness, service levels, and prices. It means that if there are more and more restaurants in the tourist detention area, the number of tourist visits tends to increase.

\section{The Influence of Total Population on LOSR in the Tourism Sector}

The results of this research indicate that the population has a positive and insignificant effect on LOSR in the tourism sector, because it has a positive regression coefficient $=0.561$, with a probability $=0.358$ which is greater than 0.05 . This means that for every $1 \%$ increase in population, the tourism sector's LOSR will increase or increase by $56.1 \%$, but the increase in LOSR $\mathrm{n}$ the tourism sector due to the population is not significant in real terms. Thus, it can be concluded that the fourth hypothesis in this research is rejected / not proven.

This result is different from the statement which states that the amount of Regional Original Income (LOSR) can be influenced by the population, if the population increases, the income earned will increase. The population determines the economy of an area. A large population and balanced with employment opportunities and a stable economy will encourage increased regional development.

\section{E. The effect of GDP per capita on LOSR in the tourism sector}

Based on the results of simple regression analysis, it shows that the GDP per capita has a positive and significant effect on LOSR in the tourism sector, because it has a positive regression coefficient $=0.623$, with a probability $=0.012$ which is smaller than 0.05 , so the fifth hypothesis which states "GRDP per capita has a positive effect on the total tourist visits "accepted / proven. It means that every increase in LOSR per capita by $1 \%$, the number of tourist visits will increase or increase by $62.3 \%$.

GRDP is a picture of the overall economy in a region. GRDP has a direct impact on regional revenue generation. GRDP is a function of LOSR. With the increase in GRDP, it will increase local government revenue which can be used to finance government programs or development of facilities and infrastructure, so as to improve services to the community which are expected to increase their productivity.

The higher a person's income, the higher the person's ability to pay various levies set by the government. In the macro concept it can be analogized that the greater the GRDP obtained, the greater the potential for regional revenue. So with an increase in GRDP, it indicates that it will encourage an increase in Local Own Source-Revenue.

\section{F. The Effect of Number of Restaurants on LOSR in the Tourism Sector}

The results of this research show that the number of restaurants has a positive and significant effect on LOSR in the tourism sector in the regencies / cities in the province of DIY, because it has a positive regression coefficient $=0.576$, with a probability of 0.004 which is smaller than 0.05 . Thus, it can be concluded that the sixth hypothesis in this research is accepted or proven. This means that for every $1 \%$ increase in the number of restaurants, the tourism sector's LOSR will increase or increase by $57.6 \%$.

It is in accordance with the results of research conducted [17] which states that the variables of restaurants and restaurants have a positive effect on regional revenue from the tourism sector in the Regency / City of Jambi Province. The availability of restaurants and restaurants in tourist areas provides opportunities for culinary tourism entrepreneurs to introduce regional specialties. Typical food can be a potential in tourism development if it is managed and developed in an integrated, professional and orderly manner. This may even be a separate attraction that will attract tourists to visit, which in turn will also make a positive contribution to regional revenue.

\section{G. The Effect of the Number of Tourist Visits on the LOSR in the Tourism Sector}

Based on the results of simple regression, it is known that the number of tourist visits has a positive and significant effect on LOSR in the tourism sector in the districts / cities in the province of DIY, because it has a positive regression coefficient $=1.787$, with a probability value of 0.000 which is smaller than 0.05. Thus, it can be concluded that the seventh hypothesis in this study which states "the number of tourist visits has a positive effect on LOSR in the tourism sector" is accepted or proven. These results mean that for each increase in the number of tourist visits by $1 \%$, the tourism sector LOSR will increase or increase by $178.7 \%$.

This result is in line with the statement that theoretically (a priori) the longer tourists stay in a tourist destination, the more money is spent in the tourist destination, at least for food purposes, drinking and lodging while staying in the area. Various kinds of tourist's need during the tour will lead to consumptive activities for products in tourist destinations. With the existence of consumptive activities from both foreign and domestic tourists, it will increase the income from the tourism sector in an area. Therefore, the higher the flow of tourist visits to the regency / city of Yogyakarta, the revenue of the tourism sector in all districts / cities of Yogyakarta will also increase. The increase in tourism sector income as a result of the increasing number of visiting foreign tourists is very important. In comparing the income of the tourism sector between countries, it is very important to look at the number of foreign tourists visiting a country, just like looking at the level of annual income. If a country is visited by a large 
number of foreign tourists each year, economically, it has the opportunity to earn higher income. These results are in line with previous research conducted by [18] which suggest that the number of tourist visits has a positive and significant effect on local revenue. From the results of the study stated that shocks to the number of tourists produce a sustainable effect [19] and [20].

\section{H. The Effect of Total Population on Local Own Source-}

Revenue in the Tourism Sector, which is mediated by the Number of Tourist Visits

Based on the Sobel test results, it can be seen that the number of tourists visits positively mediates the effect of population on Local Own Source-Revenue in the tourism sector, because it has an indirect effect regression coefficient $=$ 0.671 which is greater than the direct effect coefficient $=$ 0.561. It means that the number of tourist visits strengthens the influence of the population on LOSR in the tourism sector.

\section{The effect of GDP per capita on LOSR in the tourism sector is mediated by the number of tourist visits}

Based on the Sobel test results, it can be seen that the number of tourist visits does not mediate the effect of GDP per capita on LOSR in the tourism sector, because it has an indirect effect regression coefficient $=0.764$ which is smaller than the direct effect coefficient $=2.197$. It means that the number of tourist visits does not mediate the effect of GRDP Per capita on LOSR in the tourism sector] This is in line with the results of the study that there is a two-way tying relationship between tourism and gross domestic income in some countries in Europe [19]

\section{G. The Effect of Number of Restaurants on LOSR in the Tourism Sector, which is mediated by the Number of Tourist Visits}

Based on the Sobel test results, it can be seen that the number of tourist visits does not mediate the effect of the number of restaurants on LOSR in the tourism sector, because it has an indirect effect regression coefficient $=0.429$ which is smaller than the direct effect coefficient $=0.576$. It means that the number of tourist visits does not mediate the effect of GDRP Per capita on LOSR in the tourism sector.

\section{CONCLUSION}

Based on the result of the research above can be concluded as the result of the research. GDRB and the amount of restaurant has a positive and significant effect on the number of tourist visits,

GDRB per capita, the number of restaurant and the number of tourist visits has a positive and significant effect on LOSR of tourism sector. The population is not significant effect on LOSR but the number of tourist visits can mediate the relationship between population and LOSR tourism sector. It means that the number of tourist visits strengthens the influence of the population on LOSR in the tourism sector.

It means that the number of tourist visit strengthens population factor. For this reason, what needs to be encouraged in this regard is increasing tourist visits.

\section{ACKNOWLEDGMENT}

Our research was supported by Janabadra University through Institute for Research and Community Service (LP3M) which has funded this research.

A preliminary version of this paper was presented at the 3rd ICOBAME (International Conference on Banking, Accounting, Management and Economics (ICOBAME, 2020). Author greatest appreciation also goes to dean of the Faculty of Economics and Business and vice dean one which has facilitated researcher in full to participate in this seminar. The authors are grateful to anonymous reviewers for their helpful suggestions to improve this research.

\section{REFERENCES}

[1] UNWTO. (2017). Sustainable Tourism for Development, 1-227. Retrieved from http://www.sustainabletourismonline.com/awms/Upload/Resource/book shop/Crouch_modelDestnComp-web.pdf

[2] Melita, Mendlinger, The Impact of Tourism Revenue on the Local Communities' Livelihood: A Case Study of Ngorongoro Conservation Area, Tanzania. Journal of Service Science and Management, pp.117126

[3] Xhiliola Agaraj \& Merita Murati, "Tourism an Important Sector of Economy Development," Annals - Economy Series, Constantin Brancusi University, Faculty of Economics, vol. 1, May 2009, pages 83-90.

[4] Tourism Statistics, The Tourism and Creative Economy Agency Of The Republik Indonesia, 2019

[5] Xhiliola Agaraj \& Merita Murati, "Tourism an Important Sector of Economy Development," Annals - Economy Series, Constantin Brancusi University, Faculty of Economics, vol. 1, May 2009, pages 83-90.

[6] Novitri, Q., Junaidi, Safri, M. (2013). Determinan Penerimaan Daerah dari Sektor Pariwisata di Kabupaten/Kota Provinsi Jambi. Jurnal Perspektif Pembiayaan dan Pembangunan Daerah, Vol. 1 No. 3: 149. 158

[7] Ahmet Kara, Mehves Tarim, and Ekrem Tatoglu, 72 The Economic Social and Environmental Determinants of Tourism Revenue in Turkey: Some Policy Implications, Journal of Economic and Social Research 5 (2), 61-72

[8] E. M. Ekanayake, Bethune-Cookman, Tourism Development And Economic Growth In Developing Countries, Global Conference on Business and Finance Proceedings Volume 6 Number 22011520 man E. University Aubrey E. Long, Bethune-Cookman University

[9] Ahmet Kara, Mehves Tarim, and Ekrem Tatoglu, 72 The Economic Social and Environmental Determinants of Tourism Revenue in Turkey: Some Policy Implications, Journal of Economic and Social Research 5 (2), 61-72

[10] DIY Tourism Office, Statistik Kepariwisataan DIY 2018. Yogyakarta

[11] Ghozali, I. (2009). Aplikasi Analisis Multivariate Dengan Program SPSS. Semarang: Badan Penerbit Universitas Diponegoro.

[12] John M.Bryden, Tourism and Development : A Case Study of Commonwealth of Carribean, Cambridge University Pers,1993, p. 37.

[13] Kozak,Metin (2015) Tourism Economic : A Practical Perspective, First Published, Cambridge Scholars Publishing

[14] Lumaksono, A., Priyarsono, D.S., Kuntjoro, dan Heriawan, R. (2012). Dampak Ekonomi Pariwisata Internasional Pada Perekonomian Indonesia. Forum Pascasarjana, Vol. 35, No. 1: 53-68.

[15] Swantara, I K B P, dan Darsana, I.B. (2017). Pengaruh Kunjungan Wisatawan, Pendapatan PHR, dan Penerimaan Retribusi Obyek Wisata Terhadap PAD Kabupaten Gianyar. E-Jurnal Ekonomi Pembangunan Universitas Udayana, Vol. 6. No. 12: 251-258. 
[16] Apriyani, Fauziah. (2015). Analisis Faktor-Faktor Yang Mempengaruhi Kontribusi Sektor Pariwisata Untuk Mendukung Peningkatan Paddi Kota Palembang. PROFIT: Kajian Pendidikan Ekonomi dan Ilmu Ekonomi, Vol.2 No.2: 1-10.

[17] Suastika, I Gde Yoga dan I Nyoman Mahendra Yasa. (2017). Pengaruh Jumlah Kunjungan Wisatawan, Lama Tinggal Wisatawan Dan Tingkat Hunian Hotel Terhadap Pendapatan Asli Daerah Dan Kesejahteraan Masyarakat Pada Kabupaten/Kota Di Provinsi Bali. E-Jurnal Ekonomi Pembangunan Universitas Udayana, Vol. 6. No. 7: 1157-1394.

[18] R. Geofrey lacherand Sanjai K. Nepal, From Leakages to Linkages : Local Level Strategies for Capturing Tourism Revenue in Northern
Thailand. Tourism Geographies an International Journal of Tourism Space, Place and Enviroment, Vol. 12, 2010, pp 77-99

[19] Juan Gabriel Brida, Wiston Adrian Risso, Tourism As Determinant of Long - Run Economic Growth,

Journal of Policy Research in tourism, Leisure and event, Volume 2, 2010-Issue 1, 23 Maret 2010

[20] Xhiliola Agaraj \& Merita Murati, "Tourism an Important Sector of Economy Development," Annals - Economy Series, Constantin Brancusi University, Faculty of Economics, vol. 1, May 2009, pages 83-90. 